\title{
PENGAJARAN TEOLOGI PADAANAK USIA DINI MELALUI LAGU TRI MURTI (NYANYIAN DHARMA)
}

\author{
Oleh \\ Ida Ayu Putu Utami Dewi \\ (Asesor PAUD)
}

\begin{abstract}
Early childhood education is the main gateway in entering the next education. Conducting education as early as possible is an investment in further education as well as building a solid foundation of life. This period is a very important period, where at this time the human experience full development, so called as the golden age. Teaching theology can be done through songs. Chanting of children's songs is a powerful weapon in building theological values towards the children. They can learn about the theological value contained in the song while they are singing happily. One of the Hindu children's songs is Tri Murti. This Tri Murti song indirectly adds positive stimulus to the growth of the child. The lyrics of the song imply the concept of divinity in Hinduism with language that is easily understood by young children without having to peel deeper. Where the God of Hinduism has three main manifestations consisting of the Lord Brahma, Lord Vishnu and Lord Shiva are referred to as the three main devātas. These three gods are described as having different tasks and mastering different elements and different scriptures. With this song, young Hindu youths have been installed early on in theology and need not worry about other people's accusations that Hindus worship a lot of God; Hinduism is a religion of polytheism and so on. In this song is very clearly mentioned that there are three manifestations of God called Tri Murti with different names, different characters, and different tasks. However, in essence, it is one that is Brahman.
\end{abstract}

\section{Keywords : Theology, Early Childhood, Tri Murti}

\begin{abstract}
Abstrak
Pendidikan anak usia dini merupakan gerbang utama dalam memasuki pendidikan berikutnya. Dilakukannya pendidikan sedini mungkin merupakan sebuah investasi dalam pendidikan selanjutnya juga sekaligus sebagai pembangunan pondasi kehidupan yang kokoh. Masa ini merupakan masa yang sangat penting, dimana pada masa inilah manusia mengalami perkembangan seutuhnya, sehingga disebut sebagai golden age (usia keemasan). Pengajaran teologi dapat dilakukan melalui lagu. Pelantunan lagu anak-anak merupakan sebuah senjata jitu dalam membangun nilai-nilai teologi pada anak. Karena selain berbahagia bernyanyi bersama, ia juga belajar mengenai nilai teologi yang terkandung dalam lagu tersebut. Salah satu lagu anak-anak Hindu adalah Tri Murti. Lagu Tri Murti ini secara tidak langsung menambah rangsangan positif terhadap tumbuh kembang anak. Lirik dari lagu tersebut menyiratkan konsep ketuhanan dalam Hindu dengan bahasa yang mudah dipahami oleh anak usia dini tanpa harus mengupas lebih dalam. Dimana Tuhan dalam agama Hindu memiliki tiga manifestasi utama yang terdiri dari Dewa Brahma, Dewa Wisnu dan Dewa Siwa yang disebut sebagai tiga devāta utama. Ketiga dewa ini digambarkan memiliki tugas yang berbeda-beda dan menguasai
\end{abstract}


elemen berbeda serta aksara suci yang berbeda pula. Dengan adanya lagu ini, anak-anak muda Hindu sejak dini telah ditanamkan nilai-nilai teologi dan tidak perlu risau dengan tuduhan umat lain bahwa Hindu memuja banyak Tuhan, Hindu adalah agama politeisme dan lain sebagainya. Dalam lagu ini sangat jelas disebutkan bahwa terdapat tiga manifestasi Tuhan yang disebut Tri Murti dengan nama yang berbeda-beda, aksara berbeda dan tugas yang berbeda pula. Namun, pada hakekatnya adalah satu yakni Brahman.

\section{Kata Kunci : Teologi, Anak Usia Dini, Tri Murti}

\section{PENDAHULUAN}

Pendidikan anak usia dini merupakan gerbang utama dalam memasuki pendidikan berikutnya. Dilakukannya pendidikan sedini mungkin merupakan sebuah investasi dalam pendidikan selanjutnya juga sekaligus sebagai pembangunan pondasi kehidupan yang kokoh. Masa ini merupakan masa yang sangat penting, dimana pada masa inilah manusia mengalami perkembangan seutuhnya, sehingga disebut sebagai golden age (usia keemasan).

Disebut sebagai usia keemasan karena pada masa ini tidak kurang dari 100 miliar sel otak siap untuk dirangsang agar kecerdasan seseorang dapat berkembang dengan optimal. Pernyataan tersebut relevan dengan pernyataan Hariwijaya (2009:13) bahwa enam tahun pertama adalah masa-masa paling penting dan menentukan dalam membangun kecerdasan anak dibandingkan masa sesudahnya. Dengan kata lain, untuk mengembangkan potensi tumbuh kembang anak secara maksimal dibutuhkan pula rangsangan yang maksimal.

Demikian pula dengan nilai-nilai teologi hendaklah ditanamkan pada anak sejak usia dini. Bagaikan ilalang muda yang tajam, seorang anak usia dini mampu menangkap apa yang ada disekitarnya dan mengikuti hal-hal yang ia saksikan. Untuk membangun mental dan perilaku seorang anak, dilakukan penanaman nilai-nilai teologi sejak dini melalui nyanyian yang menyenangkan namun juga memiliki nilai yang tinggi. Misalnya seperti lagu anakanak Hindu yang berjudul "Tri Murti", dimana lagu ini mengajarkan pada anak bahwa dalam Agama Hindu terdapat begitu banyak manifestasi Tuhan dengan wujud dan tugas yang berbeda-beda namun sejatinya berasal dari yang satu (Brahman).

Pelantunan lagu anak-anak merupakan sebuah senjata jitu dalam membangun nilai-nilai teologi pada anak. Karena selain berbahagia bernyanyi bersama, ia juga belajar mengenai nilai teologi yang terkandung dalam lagu tersebut. Dengan nada yang indah dan menyenangkan, dapat mendorong sang anak menyanyikannya setiap saat hingga nilai-nilai tersebut melekat dalam hatinya. Berdasarkan pemaparan tersebut, lebih lanjut akan dibahas mengenai karakter musik bagi anak usia dini, lirik lagu Tri Murti serta makna teologi yang terkandung di dalamnya sebagai salah satu metode pembelajaran teologi pada anak usia dini. 


\section{PEMBAHASAN}

\subsection{Karakter Musik Bagi Anak Usia Dini}

Pendidikan pada anak usia dini pada hakekatnya anak belajar banyak hal melalui permainan dan lagu. Karakteristik musik untukanak usia dini merupakan musik yang memiliki struktur dan irama yang sederhana dan relatif konstan. Rachmi (2008:13) menyatakan bahwa idealnya musik untuk anak-anak usia dini mempunyai tiga komponen utama yakni memiliki vokal, mampu merangsang gerak dan dapat memberikan rangsangan untuk mendengarkan dengan seksama atau menyimak. Dimana periode ini merupakan periode eksploratif bagi anak, karena mereka masih belajar mengendalikan aktivitas anggota tubuh, baik berjalan dan berlari. Oleh karena itu, pada periode ini anak masih lebih banyak mengkoordinasikan gerak tubuh.

Lagu anak-anak ada bermacam jenisnya, baik yang mengandung nilainilai etika, nasionalisme hingga yang menyangkut dengan teologi. Salah satu diantara sekian banyak lagu anakanakHindu, yang paling menarik perhatian penulis adalah lagu yang berjudul Tri Murti. Lagu ini memiliki struktur irama yang mudah diikuti oleh anak-anak usia dini. Disamping itu, lagu Tri Murti menunjukkan kereligiusan anak Hindu.

\subsection{Pembelajaran Teologi BalikLagu Tri Murti}

Albert dalam Donder (2009:1) menyatakan secara harfiah teologi berarti "studi mengenai Allah," yang berasal dari bahasa Yunani 'theos' yang berarti Tuhan, dan akhiran '-ology' dari bahasa Yunani 'logos' yang berarti (dalam konteks ini) wacana, teori atau penalaran. Pudja (1999:3) menyatakan teologi adalah ilmu tentang Tuhan. Dalam Hindu ilmu yang mempelajari tentang Tuhan disebut Brahma Vidyā atau Brahma Tattva Jñāna. Kata "Brahma" dalam hubungan pengertian diatas dinyatakan sebagai Tuhan, Vidyā atau Jñāna berarti ilmu dan Tattva berarti hakekat tentang Tat (itu, yaitu Tuhan dalam bentuk Nirguna Brahman). Sehingga yang dimaksud Tattva Jñāna yaitu ilmu tentang Tuhan. Relevan dengan pernyataan di atas, Aryadharma dalam Sumaryani (2017:26) juga menyatakan bahwa theologi merupakan ilmu pengetahuan ilmiah tentang Tuhan. Teologi berasal dari akar kata theo + logos. Istilah teologi (theologi) telah digunakan oleh orang Yunani jauh sebelum munculnya gereja Kristen, yaitu suatu istilah yang digunakan untuk menunjuk pada suatu ilmu mengenai halhal yang berkaitan dengan Tuhan.

Berdasarkan beberapa penjelasan di atas, secara umum teologi diartikan sebagai pengetahuan tentang Tuhan. Selanjutnya, Pengajaran Teologi melalui lagu Tri Murti yang dimaksud yakni mengajarkan lagu yang menyenangkan pada anak dan sekaligus menanamkan nilai-nilai ketuhanan dalam dirinya. Dalam perkembangannya, lagu Tri Murti sejak pertama kali diciptakantelah populer di di kalangan anak-anak masa itu. Adapun lirik dari lagu Tri Murti, sebagai berikut:

Tri Murti

Tiga perwujudan Tuhan

Dalam ajaran Agama Hindu

Brahma Wisnu dan juga Siwa

Beda tugasnya jaga dunia 
Brahma Tuhan maha pencipta

Wisnu adalah pemelihara

Siwa bertugas s'bagai pelebur

Tiga wujudnya satu Tuhanku

Brahma dilambangkan 'A'

Wisnu aksaranya ' $U$ '

Siwa berlambang ' $M$ '

Ketiganya jadi Tri Murti

Jika dibahas satu persatu, Tiga perwujudan Tuhan, Dalam ajaran Agama Hindu, Brahma Wisnu dan juga Siwa, Beda tugasnya jaga duniamenunjukkan dalam ajaran agama Hindu terdapat tiga manifestasi Tuhan yang juga disebut sebagai tiga devatā utama yakni Dewa Brahma, Dewa Wisnu dan Dewa Siwa dengan tugas yang berbeda-beda.

Brahma Tuhan maha pencipta, Wisnu adalah pemelihara, Siwa bertugas s'bagai pelebur, Tiga wujudnya satu Tuhanku. Ketiga devatā ini memiliki tugas-tugas yang berbeda satu sama lain. Dewa Brahma bertugas sebagai pencipta segala macam ciptaan, Dewa Wisnu sebagai pemelihara seluruh ciptaan dan Dewa Siwa sebagai dewa pelebur segala jenis kenegatifan dan ciptaan yang sudah melewati masa aktif demi menjaga keseimbangan alam semesta.

Brahma dilambangkan 'A', Wisnu aksaranya ' $U$ ', Siwa berlambang ' $M$ ', Ketiganya jadi Tri Murti. Masing-masing devatā utama ini memiliki aksara sucinya masing-masing yakni A, U dan M. Ketika seseorang menyebut 'A' secara otomatis mulutnya akan terbuka lebar yang mencirikan penciptaan, ' $U$ ' mencirikan pemeliharaan dan ' $M$ ' dengan posisi mulut tertutup mencirikan peleburan. Gabungan dari ketiga aksara ini akan membentuk AUM atau OM yang merupakan simbol dari Brahman.

Pada perkembangan selanjutnya, lagu Tri Murti mengalami perubahan pada beberapa liriknya, namun masih mengandung nilai-nilai teologi yang sama, seperti yang tertera di bawah ini:

Tri Murti

Tiga manifesasi Tuhan Dalam ajaran Agama Hindu Brahma Wisnu dan juga Siwa Beda tugasnya untuk dunia

Brahma dewa maha pencipta Wisnu dewa pemelihara Siwa berkuasa s'bagai pelebur

Tiga nama satu Tuhanku

\section{Brahma dewanya api Wisnu dewanya air Siwa dewanya angin \\ Ketiganya jadi Tri Murti \\ (Nyanyian Dharma Edisi \\ Khusus, 2012)}

Lagu Tri Murti ini secara tidak langsung menambah rangsangan positif terhadap tumbuh kembang anak. Lirik dari lagu tersebut menyiratkan konsep ketuhanan dalam Hindu dengan bahasa yang mudah dipahami oleh anak usia dini tanpa harus mengupas lebih dalam. Dimana Tuhan dalam agama Hindu memiliki tiga manifestasi utama yang terdiri dari Dewa Brahma, Dewa Wisnu dan Dewa Siwa yang disebut sebagai tiga devatā utama (Titib, 1996:82). Ketiga dewa ini digambarkan memiliki tugas yang berbeda-beda dan menguasai elemen berbeda dan akasara yang berbeda pula. 
Brahma sebagai dewa pencipta dengan aksaranya "A" dan berkuasa atas api, Dewa Wisnu merupakan dewa yang bertugas sebagai pemelihara dengan aksaranya "U" dan berkuasa atas air, sedangkan Siwa merupakan dewa pelebur dengan aksaranya "M" dan berkuasa atas angin. Masing-masing aksara dari Tri Murti tersebut, digabungkan membentuk AUM atau OM sebagai perlambangan suci dari Brahman (Tuhan). Dalam agama Hindu, OM atau Omkara/Pranava diyakini sebagai simbol universal. Manavadharmasastra II.83 menyatakan bahwa aksara tunggal Om adalah Brahman yang tertinggi (Titib, 2003:374).

Dengan adanya lagu ini, anak-anak muda Hindu sejak dini telah ditanamkan nilai-nilai teologi dan tidak perlu risau dengan tuduhan umat lain bahwa Hindu memuja banyak Tuhan, Hindu adalah agama politeisme dan lain sebagainya. Dalam Lagu ini sangat jelas disebutkan bahwa terdapat tiga manifestasi Tuhan yang disebut Tri Murti dengan nama yang berbeda-beda, aksara berbeda dan tugas yang berbeda pula. Namun, pada kakekatnya adalah satu yakni Brahman.

\section{SIMPULAN}

Pendidikan pada anak usia dini pada hakikatnya anak belajar banyak hal melalui permainan dan lagu. Karakteristik musik untuk anak usia dini merupakan musik yang memiliki struktur dan irama yang sederhana dan relatif konstan. Idealnya musik untuk anak-anak usia dini mempunyai tiga komponen utama yakni memiliki vokal, mampu merangsang gerak dan dapat memberikan rangsangan untuk mendengarkan dengan seksama atau menyimak.
Nilai-nilai teologi dapat diberikan pada anak usia dini melalui berbagai metode, salah satunya melalui lagu. Lagu anak-anakHindu yang berjudul Tri Murtidari Nyanyian Dharma dapat membantu mengembangkan pengetahuan anak mengenai perwujudan Tuhan yang berbeda-beda dan fungsi yang berbedabeda. Namun pada hakikatnya berasal dari satu sumber yang sama (Brahman). Akan sangat baik bila anak-anak muda Hindu dibekali pengetahuan tersebut sejak dini, sehingga ia tidak perlu khawatir ketika umat lain mencemooh dan mengatakan bahwa Hindu memuja banyak Tuhan.

\section{DAFTAR PUSTAKA}

Donder, I Ketut. 2009. Teologi : Memasuki Gerbang Ilmu Pengetahuan Ilmiah Tentang Tuhan Paradigma Sanatana Dharma.Surabaya : Pāramita.

Hariwijaya, M. dan Bertiani Eka Sukaca. 2007. PAUD Melejitkan Potensi Anak dengan Pendidikan Sejak Dini. Bandung.

Pudja, Gede. 1999. Theologi Hindu (Brahma Widya). Surabaya : Pāramita.

Rachmi, Tetty. 2008. Keterampilan Musik dan Tari. Jakarta: Universitas terbuka.

Sumaryani, Ni Made. 2017. Konsep Duhkha dan Mokșa dalam Chāndogya Upaniṣad sebagai Pedoman Mencapai Kebebasan: Perspektif Teologi Pembebasan). Skripsi. Denpasar: IHDN Denpasar. Titib, I Made. 1996. Veda Sabda Suci: Peodman Praktis Kehidupan. Surabaya: Paramita. 
Titib, I Made. 2003. Teologi \& Simbol-

Simbol dalam Agama Hindu.

Surabaya: Paramita. 